Akreditasi KEMENRISTEKDIKTI, Nomor: 148/M/KPT/2020
http://iurnal.stkippersada.ac.id/jurnal/index.php/VOX

\title{
EFEKTIFITAS PENGGUNAAN MEDIA PERMAINAN TEKS DALAM KETERAMPILAN MENDENGAR DAN BERBICARA BAHASA MANDARIN
}

\author{
Weniyanti \\ Program Studi Bahasa Mandarin, Sekolah Tinggi Bahasa Harapan Bersama \\ Email:weni90yanti@gmail.com
}

\section{INFO ARTIKEL}

Riwayat Artikel:

Menerima : 21 Agustus 2020

Revisi : 1 Oktober 2020

Diterima : 27 Oktober 2020

\section{Kata Kunci:}

Bahasa Mandarin, Pengaruh, Permainan Teks

Keywords:

Mandarin, Influence, Text Game

\section{Korespondensi:}

Weniyanti

Program Studi Bahasa Mandarin, Sekolah Tinggi

Bahasa Harapan Bersama Email:

weni90yanti@gmail.com

\section{ABSTRAK}

Penguasaan bahasa Mandarin yang baik harus meliputi aspek mendengar, berbicara, menyimak dan menulis. Mata kuliah Mendengar dan Berbicara berfokus pada peningkatan kemampuan mendengar dan berbicara dengan bahasa Mandarin. Tujuan dari bahasa adalah sebagai alat berkomunikasi antar manusia dan berbicara merupakan kemampuan yang sangat penting untuk berkomunikasi. Kemampuan berbicara meliputi pelafalan yang jelas dan lancar serta intonasi yang baik. Penulis melakukan pengamatan dan analisis terhadap pembelajaran di kelas dan nilai speaking mahasiswa semester 2 program studi bahasa Mandarin Sekolah Tinggi Bahasa Harapan Bersama. Metode penelitian yang digunakan penulis adalah metode deskriptif dengan pendekatan kualitatif. Teknik yang dipakai untuk mengumpulkan data adalah melalui observasi kelas selama satu semester dan wawancara kepada dosen pengampu serta mahasiswa. Instrumen yang digunakan berupa catatan perkembangan mahasiswa dan catatan wawancara. Hasil dari penelitian ini adalah media permainan khususnya permainan teks dapat meningkatkan kemampuan mahasiswa untuk melafalkan teks dengan lancar dan tepat. Mahasiswa yang awalnya tidak bisa membaca cepat setelah mengikuti permainan ini di hampir setiap bacaan, menjadi semakin lancar dalam membaca dan termotivasi untuk bersaing dengan teman sekelasnya. Nilai rata-rata speaking saat UAS juga meningkat sebesar 0,32 dimana nilai rata-rata speaking pada saat UTS adalah 8,3 dan nilai rata-rata saat UAS menjadi 8,62. Melalui rancangan permainan yang baik dan penerapan yang tepat akan membantu pembelajaran berlangsung lebih baik dan menarik.

\section{ABSTRACT}

Good command of Mandarin must cover aspects of listening, speaking, reading and writing. The Listening and Speaking courses focus on improving listening and speaking skills in Mandarin. The purpose of language is as a means of communicating between people and speaking is a very important ability to communicate. The ability to speak includes clear and smooth pronunciation and good intonation. The author made observations and analyzes of classroom learning and students' score of speaking in semester 2 of the Mandarin Language Study Program at Sekolah Tinggi Bahasa Harapan Bersama. The research method used by the writer is descriptive method with a qualitative approach. The technique used to collect data is through class observations for one semester and interviews with lecturers and students. The instruments used were notes on student progress and interview notes. The result of this research is that game media, especially text games, can improve students' ability to pronounce text fluently and accurately. Students who initially couldn't read fast after participating in this game in almost every reading became more fluent in reading and motivated to compete with their classmates. The average speaking score at the final exam also increased by 0.32 where the average speaking score at the mid-term exam was 8.3 and the average score at the final exam was 8.62. Through good game design and proper application it will help learning to take place better and more interesting. 


\section{PENDAHULUAN}

Bahasa berfungsi sebagai alat komunikasi manusia. Sebagai bagian dari masyarakat, manusia tidak akan lepas dari kehidupan sosial yang memerlukan komunikasi, sehingga bahasa berperan penting dalam kehidupan manusia. Bahasa akan menjadi alat untuk berinteraksi dengan sesama serta menjadi kunci penting bagi manusia untuk menjelajah dunia luar. Penggunaan bahasa juga telah berakar kuat dalam kultur manusia, bahasa tidak hanya menjadi alat berkomunikasi, tetapi bahasa juga memiliki banyak fungsi sosial dan kultural.

Bahasa Mandarin merupakan bahasa resmi Tiongkok. Bahasa Mandarin memiliki jumlah penutur terbanyak di dunia serta menjadi salah satu bahasa resmi PBB. Bahasa Mandarin menjadi sangat penting karena bahasa Mandarin digunakan oleh satu miliar lebih penduduk di dunia, sehingga dengan menguasai bahasa Mandarin kita bisa berkomunikasi dengan seperlima populasi di dunia.

Negara Tiongkok merupakan negara dimana ekonominya adalah terbesar kedua di dunia sejak tahun 2013 berdasarkan total nominal GDP dan PPP serta mejadi negara eksportir dan importir terbesar di dunia. Kerjasama antara Indonesia dan Tiongkok terlihat dalam bidang perdagangan, investasi dan pendidikan. Pada April 2019 Wakil Presiden Indonesia Jusuf Kalla berdiskusi dengan Wakil Presiden Tiongkok Wang Qishan terkait kerjasama proyek Belt Road Initiative (BRI) dan Jusuf Kalla menyatakan bahwa Indonesia telah siap menjalin kerjasama dengan Tiongkok termasuk melalui kerja sama BRI.
Dalam era globalisasi peminat bahasa Mandarin di Indonesia semakin meningkat. Saat ini, hampir 60\% masyarakat Indonesia memiliki minat untuk belajar bahasa Mandarin, karena dengan menguasai bahasa Mandarin, jenjang karir seseorang akan meningkat.

Keterampilan berbahasa terdiri atas empat komponen, yaitu keterampilan mendengar/menyimak (listening skills), keterampilan berbicara (speaking skills), keterampilan menulis (writing skills), dan keterampilan membaca (reading skills). Untuk menguasai suatu bahasa dengan baik maka keempat keterampilan berbahasa ini harus ada dan keempat keterampilan ini merupakan satu kesatuan yang diperoleh dengan cara banyak praktek dan latihan.

Komunikasi lisan dilakukan dengan cara berbicara atau melakukan percakapan. Keterampilan berbicara atau yang disebut sebagai retorika merupakan seni berbicara yang dimiliki seseorang dengan tujuan berkomunikasi dengan orang lain atau menyampaikan pesan lisan secara efektif. Keterampilan berbicara tidak terlepas dari kelancaran pengucapan dengan pelafalan yang jelas dan intonasi yang baik.

Dalam mempelajari bahasa Mandarin, model pembelajaran yang lazim diterapkan pendidik adalah model pembelajaran langsung dimana peserta didik belajar dengan mengamati, mengingat dan menirukan pendidik (Mintowati, 2017).

$\begin{array}{clrr}\text { Menurut } & \text { Sudrajat } \quad \text { (2011) } & \text { model } \\ \text { pembelajaran } & \text { langsung } & \text { adalah } & \text { model } \\ \text { pembelajaran } & \text { yang menekankan } & \text { pada } \\ \text { penguasaan konsep dan/atau perubahan } & \end{array}$


perilaku dengan mengutamakan pendekatan deduktif, dengan ciri-ciri sebagai berikut: (1) transformasi dan ketrampilan secara langsung; (2) pembelajaran berorientasi pada tujuan tertentu; (3) materi pembelajaran yang telah terstuktur; (4) lingkungan belajar yang telah terstruktur; dan (5) distruktur oleh guru. Salah satu tahapan dari model pembelajaran langsung adalah latihan terstruktur. Pada tahap ini, siswa dipandu guru dalam latihan-latihan. Guru berperan dalam memberikan umpan balik kepada siswa, jika siswa benar maka guru bisa memberikan apresiasi sebagai penguatan, sebaliknya jika siswa melakukan kesalahan, guru bisa mengoreksi langsung.

Penulis melakukan observasi terhadap efektifitas penggunaan media permainan teks untuk meningkatkan kemampuan berbicara yang lancar pada mahasiswa., karena belajar bahasa Mandarin tidak lengkap rasanya jika pembelajar tidak berusaha mengucapkan katakatanya dengan lancar.

Permainan teks adalah permainan yang disusun menggunakan media powerpoint dimana teks percakapan di buku teks ataupun di luar buku teks ditampilkan dalam slide powerpoint yang akan menghilang kata per kata dalam durasi waktu yang sudah ditentukan. Tampilan slide powerpoint ini hampir sama dengan tampilan teks pada aplikasi karaoke dimana tampilan suatu kalimat akan menghilang dalam waktu yang ditentukan dan kemudian akan muncul kalimat baru. Mahasiswa harus membaca dengan lancar percakapan dalam slide tersebut dalam waktu yang telah ditentukan. Jika mahasiswa tidak lancar dalam membaca teks percakapan maka tampilan slide akan menghilang, dosen akan memberikan kesempatan kepada mahasiswa untuk mengulang membaca dari awal.

Pada bab awal, dosen pengampu mengatur waktu tampilan slide per kalimat dengan waktu yang lebih lama, dosen pengampu menyesuaikan kemampuan awal mahasiswa pada kecepatan pertukaran kalimat dalam slide. Setelah tiga kali pertemuan dengan permainan ini, dosen pengampu menambah kecepatan pertukaran kalimat sehingga mahasiswa harus membaca dengan waktu yang lebih cepat. Dalam permainan ini, percakapan dalam satu slide biasanya dibaca oleh minimal dua mahasiswa. Dosen juga menggunakan sistem pembagian kelompok dalam membaca, kelompok yang gagal membaca keseluruhan kalimat sebelum tampilan slide menghilang akan diberi hukuman oleh kelompok lain. Mahasiswa sangat antusias dalam permainan ini.

Permainan ini dilakukan hampir dalam setiap bab dalam satu semester, dosen pengampu akan melakukan observasi selama kegiatan perkuliahan kemudian melihat hasil ujian speaking UTS dan UAS, serta mewawancara mahasiswa pada pertemuan terakhir perkuliahan.

Permainan teks ini berfungsi sebagai latihan terstruktur dalam pembelajaran langsung. Peran dosen yaitu memberikan timbal balik terhadap respon mahasiswa. Dosen mengamati proses berlangsungnya permainan ini, jika mahasiswa bisa membaca dengan lancar dan tepat pelafalannya, dosen akan memberikan apresiasi. Jika mahasiswa melakukan kesalahan, dosen akan memberikan 
masukan kepada mahasiswa untuk melakukan perbaikan.

Media pembelajaran dapat berfungsi sebagai alat untuk menyampaikan pesan pembelajaran yang dapat merangsang perhatian siswa. Arsyad (2013:10) mengemukakan bahwa media pembelajaran adalah sesuatu yang digunakan pendidik untuk menyampaikan pesan atau informasi dalam proses belajar mengajar sehingga dapat menarik perhatian dan minat siswa. Gagne (1970) dalam Sadiman (2014:6) menyatakan bahwa media dapat menjadi komponen yang merangsang siswa untuk belajar. Sementara itu Briggs (1970) dalam Sadiman (2014:6) menyatakan bahwa media merupakan alat fisik yang dapat memberikan pesan serta merangsang siswa dalam belajar.

Media pembelajaran dalam kegiatan belajar mengajar dapat menjadi alat yang meransang siswa sehingga tertarik dengan pengajaran yang disampaikan. Penggunaan media pembelajaran dalam pelajaran bahasa Mandarin sangat dibutuhkan guna menunjang siswa yang aktif, kreatif dalam mengikuti pelajaran bahasa Mandarin.

Evendi, dkk (2020:10) menyatakan model pembelajaran dengan bantuan media dapat meningkatkan hasil belajar siswa.

Berdasarkan latar belakang tersebut, rumusan permasalahan yang muncul adalah sebagai berikut.

1. Bagaimana penerapan media permainan teks pada mahasiswa semester 2 Program Studi S1 Bahasa Mandarin STB
Harapan Bersama dalam mata kuliah Keterampilan Mendengar dan Berbicara?

2. Bagaimana pengaruh media permainan teks terhadap kelancaran berbicara dengan bahasa Mandarin pada mahasiswa semester 2 Program Studi S1 Bahasa Mandarin STB Harapan Bersama dalam mata kuliah Keterampilan Mendengar dan Berbicara?

3. Bagaimana respon mahasiswa semester 2 Program Studi S1 Bahasa Mandarin STB Harapan Bersama tahun ajaran 2018/2019 terhadap media permainan teks dalam mata kuliah Keterampilan Mendengar dan Berbicara?

Sesuai dengan rumusan permasalahan di atas maka tujuan dari penelitian ini adalah sebagai berikut.

1. Mendeskripsikan penerapan media permainan teks pada mahasiswa semester 2 Program Studi S1 Bahasa Mandarin STB Harapan Bersama dalam mata kuliah Keterampilan Mendengar dan Berbicara.

2. Mendeskripsikan pengaruh media permainan teks terhadap kelancaran berbicara bahasa Mandarin pada mahasiswa semester 2 Program Studi S1 Bahasa Mandarin STB Harapan Bersama dalam mata kuliah Keterampilan Mendengar dan Berbicara.

3. Mendeskripsikan respon mahasiswa semester 2 Program Studi S1 Bahasa Mandarin STB Harapan Bersama tahun ajaran 2018/2019 terhadap media permainan teks dalam mata kuliah Keterampilan Mendengar dan Berbicara.

\section{METODE PENELITIAN}

Dalam penelitiannya, penulis menggunakan metode deskriptif. Subana 
(2005: 89) menyatakan bahwa metode deskriptif menuturkan data tentang fakta atau kondisi sesungguhnya dari variabel dan fenomena yang berlangsung saat penelitian dilakukan. Melalui metode penelitian deskriptif penulis bermaksud menggambarkan atau mendeskripsikan kemampuan berbicara dengan bahasa Mandarin pada mahasiswa semester 2 dengan menggunakan permainan teks.

Pendekatan penelitian yang digunakan penulis adalah pendekatan kualitatif dimana dalam mendeskripsikan objek penelitian dan dalam menganalisa keefektifan. Permainan ini dinilai efektif apabila dalam observasinya mahasiswa mengalami peningkatan dalam kualitas membaca dan pelafalan. Dosen dapat mengamati langsung perkembangan mahasiswa di kelas. Hal ini juga dibuktikan dengan peningkatan nilai speaking mahasiswa baik saat UTS maupun UAS. Menurut Moleong (2007:3), pendekatan kualitatif adalah penelitian yang hasilnya berupa data deskriptif yaitu data lisan maupun tertulis yang diobservasi dari objek penelitian.

Penelitian ini dilakukan pada mahasiswa semester 2 program studi S1 bahasa Mandarin Sekolah Tinggi Bahasa Harapan Bersama tahun ajaran 2018/2019. Penulis juga merupakan dosen pengampu mata kuliah Keterampilan Mendengar dan Berbicara sehingga penulis dapat melakukan observasi langsung dan kemudian menganalisa secara langsung pula keefektifan penggunaan media permainan teks.

Dalam hal analisis data kualitatif, (Sugiyono, 2012) menyataka bahwa analisis data adalah kegiatan pencarian dan penyusunan data dari proses wawancara secara teratur, sehingga lebih mudah dimengerti dan hasil analisis data ini dapat lebih mudah diinformasikan ke orang lain.

Teknik yang dipakai untuk mengumpulkan data adalah melalui observasi kelas selama satu semester dan wawancara kepada dosen pengampu serta mahasiswa. Untuk observasi kelas, karena peneliti juga merupakan dosen pengampu mata kuliah mendengar dan berbicara, maka dosen dapat dengan mudah melakukan observasi kelas. Instrumen yang digunakan berupa catatan perkembangan mahasiswa. Dalam setiap pertemuan bab, dosen yang di sini adalah penulis sendiri mempraktekkan permainan teks. Penulis akan mengamati perkembangan setiap mahasiswa dan menuliskannya ke dalam buku catatan. Buku catatan berisi informasi untuk setiap pertemuan perkuliahan, mahasiswa yang bisa membaca dengan lancar sesuai waktu yang telah diatur dalam powerpoint permainan ataupun mahasiswa yang melakukan kesalahan akan dicatat. Untuk mahasiswa yang belum bisa membaca dengan lancar akan diberikan kesempatan lebih banyak lagi pada pertemuan selanjutnya. Dosen akan terus mengamati perkembangan mahasiswa selama satu semester. Untuk kelas yang diampu oleh dosen lain, penulis melakukan wawancara terhadap dosen tersebut dan mencatat hasil wawancara ke dalam buku catatan. Melalui wawancara terhadap dosen lain, penulis dapat mengetahui efektifitas penggunaan permainan teks di kelas lain. Selain wawancara terhadap dosen, penulis juga melakukan wawancara terhadap mahasiswanya. Hal ini dilakukan untuk 
mengetahui bagaimana tanggapan mahasiswa terhadap pembelajaran satu semester khususnya tanggapan untuk pengaplikasian permainan teks. Penulis ingin mengetahui apakah mahasiswa selama satu semester antusias dengan permainan teks dan termotivasi untuk bersaing selama permainan sehingga meningkatkan kemampuan membaca.

\section{HASIL DAN PEMBAHASAN}

a. Hasil

Hasil penelitian didapatkan setelah dilakukan observasi selama satu semester pada mahasiswa semester 2 prodi $\mathrm{S} 1$ bahasa Mandarin STB Harapan Bersama. Hasil penelitian dijabarkan sebagai berikut.

\section{Hasil Analisis Data Observasi}

Dosen pengampu mata kuliah di sini merupakan penulis sendiri sehingga penulis melakukan observasi secara langsung terhadap mahasiswa. Penulis mengetahui secara jelas bagaimana permainan diterapkan pada mahasiswa dan bagaimana pengaruh serta kondisi kelas dan perkembangan mahasiswa setelah permainan ini diterapkan selama satu semester.

Penerapan permainan teks sangat baik dan mendapatkan respon yang baik dari mahasiswa. Mahasiswa sangat antusias dalam permainan ini terutama jika diadakan secara berkelompok dan ada hukuman bagi kelompok yang kalah. Mahasiswa akan berusaha untuk tampil dengan baik agar tidak mendapatkan hukuman dari kelompok lain. Suasana kelas ketika diadakan permainan ini menjadi seru dan mahasiswa menjadi lebih aktif. Menurut Suyatna (2005:12), permainan menjadi lebih menarik dan menghibur apabila terdapat unsur persaingan di dalamnya.

Saat pertama kali permainan ini diterapkan, mahasiswa belum bisa membaca dengan lancar sehingga teks akan menghilang duluan sebelum selesai dibacakan secara keseluruhan. Pada pertemuan bab kedua dan ketiga, mahasiswa sudah mulai bisa membaca dengan lebih lancar, walaupun belum semua mahasiswa bisa membaca dengan intonasi yang jelas. Pada pertemuan bab keempat mahasiswa sudah terbiasa dengan permainan ini dan sudah bisa membaca dengan lancar sehingga dosen mulai menerapkan kompetisi ke dalam permainan. Mahasiswa menjadi terpacu untuk membaca dengan lancar tanpa kesalahan sehingga kelompoknya bisa menang. Dari pertemuan ke pertemuan, kemampuan mahasiswa dalam membaca atau pelafalan saat membaca teks semakin meningkat.

Tujuan diadakan permainan dalam proses pembelajaran adalah untuk supaya suasana belajar lebih menyenangkan serta mengubah suasana belajar yang pasif ke aktif sehingga tujuan belajar dapat tercapai dengan lebih efisien dan efektif.

\section{Hasil Analisis Data UTS dan UAS}

UTS diadakan setelah 6 Bab pertemuan harian. Untuk menilai efektifitas penggunaan media permainan teks maka ada satu bagian soal ujian lisan yang berisi 10 kalimat yang harus dibaca mahasiswa dengan lancar, nada dan intonasi jelas serta pelafalan baik. Mahasiswa merekam jawaban ujian lisan di laboratorium bahasa kemudian dosen pengampu akan menilai rekaman mahasiwa. Nilai atau skor maksimal untuk soal ujian lisan 
bagian ini adalah 10, dan semua mahasiswa pada kelas yang diuji mendapatkan nilai di atas 7 dengan rata-rata nilai 8,3. Hal ini menunjukkan pada saat UTS mahasiswa sudah bisa membaca kalimat dengan lancar dan tepat.

Setelah UTS, permainan ini tetap diterapkan pada mahasiwa dan dinilai kembali saat UAS. Nilai atau skor maksimal UAS untuk soal ujian lisan bagian membaca kalimat juga sama dengan UTS yaitu 10, dan semua mahasiswa pada kelas yang diuji mendapatkan nilai di atas 7,5 dengan rata-rata nilai 8,62. Berdasarkan perbandingan nilai rata-rata UTS dan UAS, maka terlihat ada peningkatan nilai sebesar 0,32. Melalui permainan yang dilakukan selama satu semester ini, mahasiswa dapat membaca dengan lancar dengan intonasi yang baik.

3. Hasil Analisis Data Wawancara Dosen Pengampu

Untuk memastikan bahwa media permainan teks efektif dalam pembelajaran bahasa Mandarin terutama pada kelancaran membaca dan berbicara, penulis juga melakukan wawancara kepada dosen pengampu mata kuliah Keterampilan Mendengar dan Berbicara di kelas lain. Dari hasil wawancara disimpulkan bahwa media permainan teks cukup efektif dalam meningkatkan kualitas pembelajaran. Mahasiswa semakin terlatih untuk membaca dengan lancar dan nilai speaking juga mengalami peningkatan yang signifikan.

4. Hasil Analisis Data Wawancara Mahasiswa

Manfaat dari penerapan permainan dalam kegiatan belajar antara lain: (1) membuat suasana belajar tidak terlampau serius; (2) mengurangi tekanan selama belajar; (3) mengajak siswa terlibat secara aktif dalam kegiatan belajar; (4) meningkatkan proses aktivitas belajar (Meier, 2005:206). Suyatna (2205:15) menyatakan bahwa permainan tidak selalu dapat mempercepat proses pembelajaran, namun permainan yang dilaksanakan dengan baik dan tepat dapat menambah variasi, semangat, dan minat pada kegiatan belajar (Suyatna, 2005:15).

Pada pertemuan terakhir mata kuliah keterampilan mendengar dan berbicara semester 2, dosen pengampu melakukan wawancara dengan mahasiswa. Mahasiswa diminta memberikan tanggapan atas permainan yang dilakukan selama satu semester tersebut. Seluruh mahasiswa memberikan respon yang positif dan menyukai permainan tersebut. Melalui permainan ini mahasiswa mengaku terpacu untuk membaca dengan baik dan mahasiswa juga banyak latihan membaca di rumah agar tidak banyak melakukan kesalahan dalam kelas selama proses belajar.

b. Pembahasan

Berdasarkan hasil analisis data observasi, hasil data UTS dan UAS, hasil analisis data wawancara dosen pengampu serta hasil analisis data wawancara mahasiswa dapat disimpulkan bahwa permainan teks berpengaruh baik terhadap pembelajaran. Permainan teks selain dapat meningkatkan kemampuan membaca mahasiswa, meningkatkan nilai speaking, juga membuat suasana pembelajaran menjadi lebih menarik dan menyenangkan. 


\section{SIMPULAN}

Berikut adalah simpulan dari penelitian yang dilakukan:

1. Penerapan media permainan teks pada mahasiswa semester 2 Program Studi S1 Bahasa Mandarin STB Harapan Bersama dalam mata kuliah Keterampilan Mendengar dan Berbicara telah menjawab rumusan masalah yang pertama. Berdasarkan observasi yang dilakukan langsung oleh penulis yang juga menjadi dosen pengampu mata kuliah tersebut, aktivitas permainan ini sangat baik dan menciptakan suasana belajar yang menyenangkan.

2. Pengaruh penggunaan media permainan teks telah terjawab dengan nilai UTS dan UAS mahasiswa pada ujian lisan mata kuliah Keterampilan Mendengar dan Berbicara. Nilai UTS dan UAS pada ujian lisan bagian membaca kalimat sangat memuaskan dimana untuk UTS, mahasiswa mendapat nilai di atas 7 sedangkan untuk UAS nilai mahasiswa di atas 7,5 .

3. Respon mahasiswa semester 2 Program Studi S1 Bahasa Mandarin STB Harapan Bersama tahun ajaran 2018/2019 terhadap media permainan teks dalam mata kuliah Keterampilan Mendengar dan Berbicara didapatkan melalui wawancara terhadap mahasiswa dan hasilnya mahasiwa merespon dengan sangat positif. Permainan ini dapat menciptakan persaingan antar mahasiswa sehingga mereka ingin tampil dengan lebih baik.

Berdasarkan kesimpulan di atas, penerapan permainan dalam proses pembelajaran merupakan hal yang positif. Bagi dosen, menerapkan permainan ke dalam proses belajar bisa dijadikan bahan pertimbangan untuk menciptakan suasana belajar yang lebih aktif dan menyenangkan. Permainan teks ini sangat mudah dilakukan dan tidak memerlukan persiapan yang rumit. Dosen hanya perlu menyiapkan slide powerpoint saja, tentunya dosen juga harus mengatur waktu pergantian slide yang cocok dengan kemampuan mahasiswa kemudian ditingkatkan perlahan sampai mahasiswa bisa membaca teks dengan lancar. Dosen perlu untuk selalu melakukan inovasi dalam mengajar dan salah satunya adalah dengan merancang permainan.

Bagi siswa, dalam proses pembelajaran diperlukan siswa yang selalu aktif dalam mengikuti arahan dosen. Semenarik apapun materi maupun persiapan dosen, jika tidak didukung oleh siswa yang aktif dan mau mengikuti arahan, maka proses belajar akan kurang maksimal dan menjadi membosankan. Siswa harus memiliki kepercayaan diri dan berani tampil aktif dalam proses belajar.

\section{DAFTAR RUJUKAN}

Arsyad, Azhar. 2013. Media Pembelajaran. Jakarta: Rajawali Pers

Evendi, Mohamad Taufik, Awang, Imanuel Sairo \& Supiandi, Markus Iyus. 2020. Peningkatan Hasil Belajar Siswa Menggunakan Pembelajaran Tandur Berbantuan Media Puzzle. Sintang: STKIP Persada Khatulistiwa.

Mintowati. 2017. Pembelajaran Bahasa Mandarin di Sekolah: Pendekatan dan Metode Aternatif. Dalam Jurnal Cakrawala Mandarin.[Online] Tersedia : 
http://jurnalapsmi.org/index.php/CM/art icle/download/25/11 [28 Juni 2018]

Nurjaman, Agus. 2018. Kumpulan Artikel Pendidikan Guru Figur Sentral dalam Pendidikan. Bogor: Guepedia

Sadiman, Arief S, dkk. 2014. Media Pendidikan: Pengertian, Pengembangan, Pemanfaatannya. Jakarta: PT RajaGrafindo Persada.

Subana, M dan Sudrajat, 2005, Dasar-Dasar Penelitian Ilmiah, Bandung: Pustaka Setia

Sudrajat, A. 2011. Model Pembelajaran Langsung (Direct Instruction). Http://akhmadsudrajat.wordpress.com

Sugiyono. 2012. Metode Penelitian Kuantitatif, Kualitatif Dan R\&D. Bandung: Alfabeta.

https://www.medcom.id/ekonomi/makro/Wb7j $1 \mathrm{GnN}$-indonesia-tiongkok-perkuatkerja-sama-ekonomi

http://makalahmandarin.blogspot.com/2014/12 /minat-belajar-bahasa-mandarin-diera.html 